\title{
Stocker cattle response to grazing management in tallgrass prairie
}

\author{
F. TED MCCOLLUM III, ROBERT L. GILLEN, BROCK R. KARGES, AND MARK E. HODGES
}

Authors are beef cattle extension specialist, Texas A\&M University, Amarillo, Tex. 79106; rangeland scientist, USDA-ARS, Woodward, Okla. 73801; herdsman, Department of Animal Science, Oklahoma State University, Stillwater, Okla. 74078; and executive secretary, Oklahoma Wheat Commission, Oklahoma City, Okla. 73105. At the time the research was conducted McCollum was professor, Department of Animal Science, and Gillen was professor, Department of Plant and Soil Sciences, Oklahoma State University, Stillwater, Okla. 74078.

\begin{abstract}
The effects of stocking rate and grazing method on performance of yearling beef cattle grazing tallgrass prairies in north-central Oklahoma were evaluated from 1989 to 1994. Pastures dominated by big bluestem [Andropogon gerardii Vitman], little bluestem [Schizachyrium scoparium (Michx.) Nash], and indiangrass [Sorghastrum nutans (L.) Nash], were allocated to either short duration rotational or continuous stocking methods and stocking rates ranging from 52 animalunit-days (AUD) ha ${ }^{-1}$ to 90 AUD ha. ${ }^{-1 .}$ Steers grazed the units from late April to late September. Precipitation was above average during the study period. Live weight gain per head was higher under continuous stocking than rotational stocking at all stocking rates. At 52 AUD ha ${ }^{-1}$, individual gains under rotational stocking were $11 \%$ less than under continuous stocking. At 90 AUD ha ${ }^{-1}$, individual gains under rotational stocking were decreased by $20 \%$. Measurements of steer diets and forage standing crop suggest the reduction in weight gain was due to reduced forage intake under rotational stocking. Live weight gain per hectare increased with stocking rate and was higher with continuous stocking at all stocking rates. Net returns per hectare increased as stocking rate increased for both stocking methods but were lower for rotational stocking at all stocking rates. Variable costs per head would have to decrease by 24 to $34 \%$ under rotational stocking to equalize net returns between the 2 grazing methods. Unless the decline in gain per head can be reduced or eliminated, there is no economic incentive to implement rotational stocking under the conditions of this study.
\end{abstract}

Key Words: stocking rate, grazing method, continuous stocking, rotational stocking, average daily gain

Short duration rotational stocking has been suggested as a method for increasing stocking rate while maintaining range condition (Booysen and Tainton 1978, Savory 1978). Some land managers reported dramatic improvement in carrying capacity after implementation of rotational stocking (Howell 1978, Merrill 1983). Research studies have

Approved for publication by the Director, Oklahoma Agricultural Experiment Station. This research was supported under project H-2089. Authors wish to thank Bob McDaniel and John Weir for assistance in livestock movement in rotational units and Kenneth Tate for facilities development.

Manuscipt accepted 24 May 1998.

\section{Resumen}

De 1989 a 1994, se evaluaron los efectos de la carga animal y el método de apacentamiento en el comportamiento de novillos para carne apacentando praderas de zacates altos en la región norte-central de Oklahoma. Los potreros dominados por "Big Bluestem" [Andropogon gerardii Vitam]. "Little bluestem" [Schizachyruim scoparium (Mitch) Nash] e "Indiangrass" [Sorghastrum nutans (L.) Nash] fueron asignados a los métodos de apacentamiento rotacional de corta duración y continuo, con cargas animal que fluctuaron de 52 a 90 unidades-animal-día (UAD) ha' $\mathbf{h a s}^{-1}$ Los novillos apacentaron las unidades de fines de Abril a fines de Septiembre. Durante el período de estudio la precipitación fue superior al promedio. La ganacia de peso vivo por cabeza, en todas las carga animal, fue mayor en el método continuo que en el rotacional. Con $52 \mathrm{UAD}$ ha $^{-1}$ las ganancias individuales bajo el método rotacional fueron $11 \%$ menos que las del método continuo. Con 90 UAD ha ${ }^{-1}$ las ganacias individuales bajo el método rotacional decrecieron en $20 \%$. Mediciones de la dieta de los novillos y de forraje en pie sugieren que la reducción en la ganacia de peso se debió a un consumo reducido de forraje bajo el método rotacional. La ganacia de peso por hectárea se incrementó con la carga animal y fue mayor con el método continuo para todas las cargas animal. En ambos métodos de apacentamiento los retornos netos por hectárea se incrementaron conforme la carga animal aumento, pero fueron menores para el método rotacional en todas las cargas animal. Para tener retornos netos iguales en los dos sistemas de apacentamiento, los costos variables por cabeza deberían disminuir de 24 a $34 \%$ en el método rotacional. A menos de que la disminución de la ganancia de peso por cabeza pudíera ser reducida o eliminada, no hay incentivo económico para implementar el método rotacional bajo las condiciones en las que se llevó a cabo el estudio.

reported large increases in live weight gain per hectare for rotational stocking compared to continuous stocking (Heitschmidt et al. 1982, Sedivec et al. 1990). Such studies often compared continuous stocking at a moderate stocking rate and rotational stocking at a rate $50-100 \%$ higher. Changes in stocking method were confounded with changes in stocking rate. When tested at the same stocking 
rates, the 2 stocking systems have produced little change in gain per head or per hectare (Hart et al. 1988, Olson and Malechek 1988). Hart (1978) speculated the effect of grazing methods on livestock performance would be dependent on stocking rate.

We studied the impact of grazing method and stocking rate on several characteristics of a tallgrass prairielivestock production system including herbage dynamics, grazing behavior, and livestock production. In this paper we report the effects of continuous and rotational stocking methods at several stocking rates on performance of yearling beef cattle and net economic returns.

\section{Study Area}

The study was conducted from 1989 to 1994 at the Oklahoma State University Research Range, located approximately $21 \mathrm{~km}$ southwest of Stillwater, Okla. $\left(36^{\circ} 22^{\prime} \mathrm{N}, 9^{\circ} 04^{\prime} \mathrm{W}\right.$, elev. $280 \mathrm{~m}$ ). The climate is continental with an average frost-free growing period of 204 days, extending from April through October. Average annual precipitation for the area is $831 \mathrm{~mm}$ with $65 \%$ falling as rain from May to October. The mean annual temperature is $15^{\circ} \mathrm{C}$, and ranges from an average daily minimum of $-4.3^{\circ} \mathrm{C}$ in January to an average daily maximum of $34^{\circ} \mathrm{C}$ in August (Myers 1982).

Major range sites on the study area are shallow prairie (33\%), loamy prairie $(25 \%)$, and eroded prairie (22\%). Sandy savannah dominates the remaining area. The shallow prairie sites have Grainola series soils (fine, mixed, thermic Vertic Haplustalf), which have a loam surface with silty clay subsoil. Coyle series soils (fineloamy, siliceous, thermic Udic Argiustoll) comprise the loamy prairie sites. These soils have fine sandy loam surfaces with sandy clay loam subsoils. The eroded prairie sites are on old fields and have Renfrow (fine, mixed, thermic Udertic Paleustoll), Mulhall (fine-loamy, siliceous, thermic Udic Paleustoll), and Coyle series soils.

Vegetation on the experimental units was typical of tallgrass prairie in a high seral state. Dominant grasses included little bluestem [Schizachyrium scoparium (Michx.) Nash], big bluestem [Andropogon gerardii Vitman], and indiangrass [Sorghastrum nutans (L.) Nash]. Secondary grasses included switchgrass [Panicum virgatum L.], tall dropseed [Sporobolus asper (Michx.) Kunth ], sideoats grama [Bouteloua curtipendula (Michx.) Torr. ], and Scribner's dicanthelium [Dicanthelium oligosanthes (J.A. Schultes) Gould]. The dominant forb was western ragweed [Ambrosia psilostachya DC]. All units had been moderately grazed in the 5 years previous to initiation of the study. The units had been burned either 1 or 2 times in late spring during the same period.

\section{Methods}

The experimental treatment factors were grazing method and stocking rate. Six of 12 experimental land units were assigned to a continuous stocking method, and the remaining 6 units were assigned to a rotational stocking method. All treatment assignments were random. The continuous units consisted of an undivided pasture while the rotational units were subdivided into 8 paddocks. Experimental units ranged in size from 14 to 26 ha. Within each grazing method the units were randomly allocated to 1 of 6 levels of stocking rate. Stocking rates ranged from 52 animal-unit-days (AUD) ha $\mathrm{h}^{-1}$ to 90 AUD ha ${ }^{-1}$, which represented moderate to very heavy rates for this range type. Cattle numbers per unit ranged from 10 to 22 .

Cattle in the rotational units remained in a single herd and were moved among paddocks. Grazing schedules in the rotational units were originally designed to provide 38 days average rest for each paddock between grazing periods. We shortened the rest and grazing periods in the early portion of the growing season and lengthened the rest and grazing periods as the growing season progressed. Average grazing periods ranged from 3.5 to 6.5 days from the early to the late season. After the first 2 years, target rest periods were shortened to 32 days. Grazing periods ranged from 3 to 5 days. Grazing periods for an individual paddock were adjusted for the relative forage production potential in that paddock compared to other paddocks in the same grazing unit. Cattle in the continuously stocked units were not moved during the grazing season. All units were burned 1 April 1990 and 20 March 1993.

The experimental animals were mixed-breed yearling beef cattle (Bos taurus x Bos indicus; maximum 1/8 B. indicus) typical of commercial stocker cattle originating in the southeastern U.S. Initial cattle weights were $211 \mathrm{~kg}$ $( \pm 19 \mathrm{~kg})$. Steers were used in all years except 1989 when heifers were used. Cattle were weighed at the beginning, mid point, and end of the grazing season. Average weigh dates were 26 April, 14 July, and 22 September. Cattle were gathered in late afternoon, held off feed and water overnight, and weighed early the next morning. Cattle were implanted with Synovex$\mathrm{S}^{1}$ for steers or Synovex-H for heifers (Ft. Dodge Animal Health, Princeton, N.J.) at the beginning and mid point of the grazing season.

We analyzed the data using linear regression analysis. The dependent variable was live weight gain per head. Independent variables were grazing method and stocking rate. The qualitative variable grazing method was coded as 0 or 1 for continuous or rotational stocking (Neter and Wasserman 1974). The quantitative variable stocking rate was expressed as animal-unit-days (AUD) per hectare. Animal units were calculated as body weight ${ }^{0.75} / 454^{0.75}$ (Vallentine 1990) using the body weights at the beginning of the 149 day grazing period. The initial regression model contained terms for grazing method, stocking rate (linear), and the interaction of grazing method and stocking rate. Non-significant variables were then dropped from the model until all remaining variables were significant $(\mathrm{P}=0.05)$.

\footnotetext{
${ }^{\mathrm{T}}$ Names are necessary to report factually on available data; however, the USDA neither guarantees nor warrants the standard of the product, and the use of the name by USDA implies no approval of the product to
} the exclusion of others that may also be suitable. 


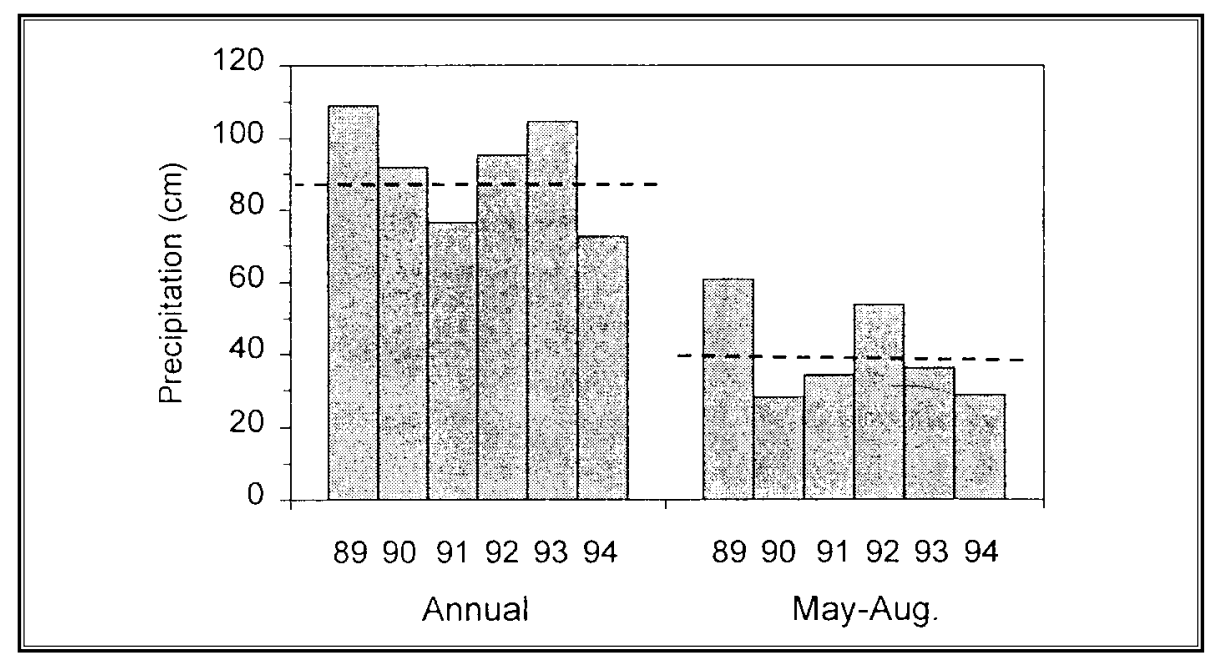

Fig. 1. Annual and May to August precipitation received at the Oklahoma State University Research Range, Stillwater, Okla., 1989 to 1994. Dotted line denotes long-term average, 1893 to 1980.

In these models, the intercept coefficient was the intercept for continuous stocking. A significant grazing method term in the regression model indicated different intercepts for the 2 grazing methods. The coefficient for grazing method was added to the intercept coefficient for continuous stocking to determine the intercept for rotational stocking. A negative coefficient for grazing method meant that rotational stocking had a lower intercept than continuous stocking. The stocking rate term was the slope of the gain versus stocking rate relationship for continuous stocking. The grazing method by stocking rate term was the difference between the slope for continuous stocking and the slope for rotational stocking. If the grazing method by stocking rate term was not significant, the slope of gain versus stocking rate was equal between the 2 grazing methods.

Initially, we developed regression models for each year individually. We also averaged the live weight gains over years and developed a single regression based on the average gains. The model based on average gains was used for subsequent analyses.

Gain per hectare was calculated by multiplying the regression equation for gain per head by stocking rate. Net return per hectare was calculated using the methods of Hart et al. (1988). Variable costs for steer production were estimated at $\$ 70$ per

\section{Results and Discussion}

Annual precipitation was well above the long-term average in 4 of the 6 study years (Fig. 1). Precipitation from May to August, the main portion of the growing season, was above average for the entire study period and was not less than $79 \%$ of average for any single year (Fig. 1). Overall weather conditions were generally favorable for forage production during the study period with cumulative precipitation above average and spring and summer temperatures slightly below average.

\section{Gain per Head}

Average gain per head over all treatments was $108 \mathrm{~kg}$ or $0.72 \mathrm{~kg} \mathrm{hd}^{-1} \mathrm{~d}^{-1}$. Of this total gain, $73 \mathrm{~kg}(68 \%)$ occurred in the first 79 days (53\%) of the grazing season.

Total live weight gain per head generally decreased as stocking rate increased for both grazing methods (Fig. 2). This decrease $(\mathrm{P}<0.05)$ was significant in 4 of 6 years for continuous stocking and 5 of 6 years for rotational stocking (Table 1). This is a classical response of individual animal performance to stocking rate (Wilson and MacLeod 1991). While there was a negative linear relationship between total gain per head and stocking rate, the slope coefficients were relatively small (Table 1).

\begin{tabular}{|c|c|c|c|c|c|c|c|c|}
\hline Year & $\mathrm{N}$ & Intercept & $\begin{array}{l}\text { Grazing } \\
\text { method }\end{array}$ & $\begin{array}{c}\text { Stocking } \\
\text { rate }\end{array}$ & $\begin{array}{l}\text { Grazing method } \\
* \text { Stocking rate }\end{array}$ & $\mathrm{R}^{2}$ & C.V. & MSE \\
\hline 1989 & 12 & $\begin{array}{l}104.6^{1} \\
(2.2)^{2}\end{array}$ & & & $\begin{array}{c}-0.188 \\
(0.044)\end{array}$ & 0.65 & 5.5 & 5.39 \\
\hline 1990 & 12 & $\begin{array}{r}173.9 \\
(9.9)\end{array}$ & $\begin{array}{r}-27.3 \\
(3.4)\end{array}$ & $\begin{array}{l}-0.485 \\
(0.139)\end{array}$ & & 0.89 & 4.7 & 5.95 \\
\hline 1991 & 12 & $\begin{array}{r}117.7 \\
(9.2)\end{array}$ & & $\begin{array}{l}-0.309 \\
(0.134)\end{array}$ & $\begin{array}{c}-0.227 \\
(0.047)\end{array}$ & 0.78 & 6.4 & 5.68 \\
\hline 1992 & 12 & $\begin{array}{r}107.1 \\
(2.6)\end{array}$ & $\begin{array}{r}-11.6 \\
(3.7)\end{array}$ & & & 0.50 & 6.3 & 6.40 \\
\hline 1993 & 12 & $\begin{array}{r}156.9 \\
(8.5)\end{array}$ & $\begin{array}{r}-10.7 \\
(2.9)\end{array}$ & $\begin{array}{c}-0.448 \\
(0.119)\end{array}$ & & 0.75 & 4.2 & 5.09 \\
\hline 1994 & 12 & $\begin{array}{l}158.3 \\
(14.2)\end{array}$ & & $\begin{array}{c}-0.504 \\
(0.206)\end{array}$ & $\begin{array}{c}-0.369 \\
(0.072)\end{array}$ & 0.80 & 7.9 & 8.73 \\
\hline
\end{tabular}

${ }_{2}$ All coefficients significant, $\mathrm{P}<0.05$.

${ }^{2}$ Standard error of estimate. 

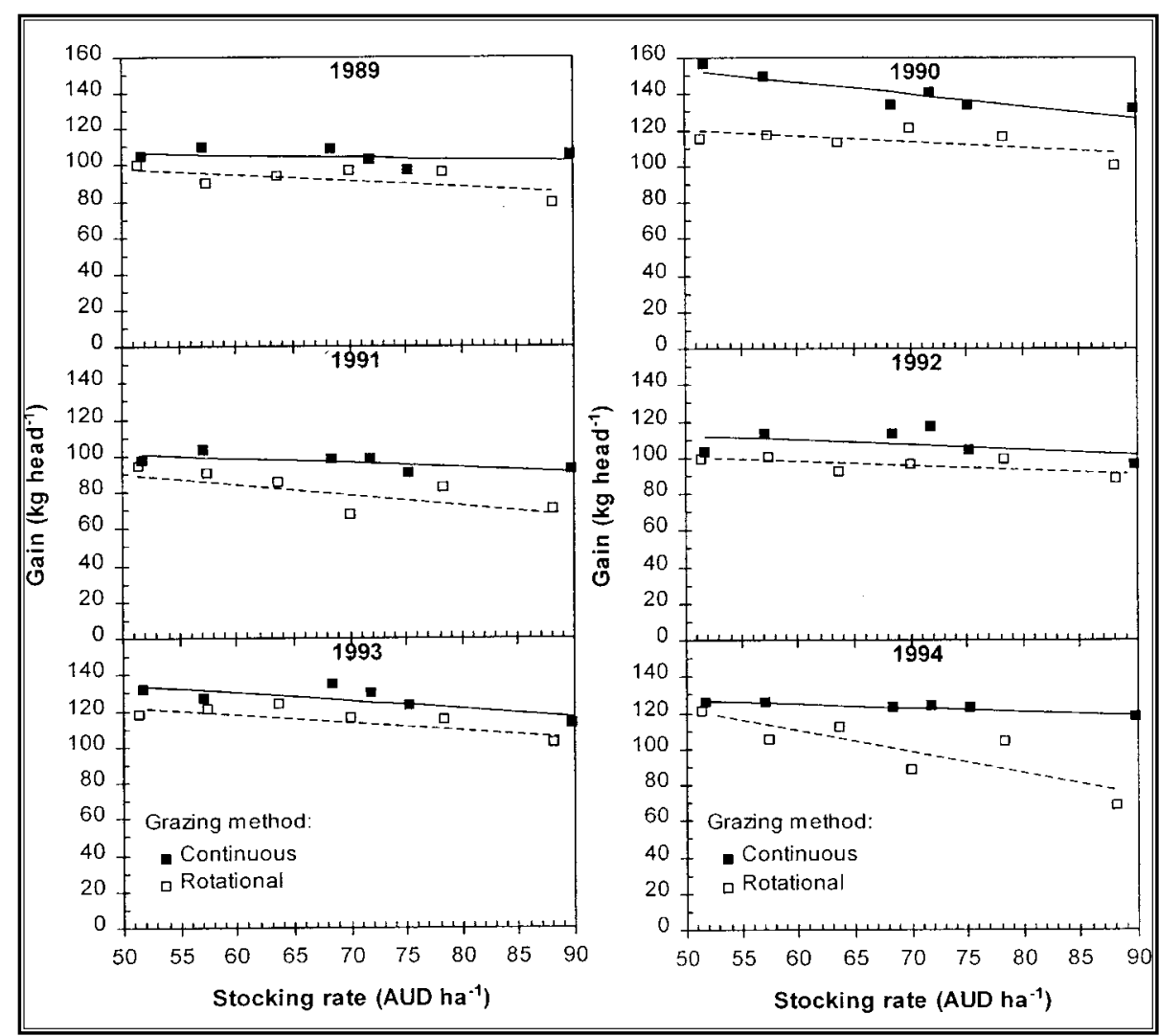

Fig. 2. Total steer gain $\left(\mathrm{kg} \mathrm{head}^{-1}\right)$ under continuous and rotational stocking methods for each year, 1989 to 1994.

Total live weight gain per head was greater $(\mathrm{P}<0.05)$ under continuous stocking than rotational stocking at all stocking rates in every year (Table 1 , Fig. 2). The negative effect of stocking rate on live weight gain was more severe under rotational stocking in 3 of 6 years and equal between grazing methods in the other years. Only the size of the difference between continuous and rotational stocking varied over years. Individual live weight gains were consistently higher under continuous stocking.

To simplify further discussion, we averaged live weight gains over years within grazing methods and stocking rates and fit a single regression model to the average gains (Table 2, Fig. 3a). Live weight gain for the full grazing season decreased as stocking rate increased $(\mathrm{P}<0.01)$. This result was previously indicated by the individual year analyses. Comparing the highest and lowest stocking rates, gain per head decreased $13-14 \%$ as stocking rate increased $74 \%$. The difference between the grazing methods al stocking treatment. In addition, endof-season standing crop across all stocking rates averaged $20 \%$ higher on the rotational units (Cassels et al. 1995). Finally, a higher proportion of little bluestem tillers remained ungrazed over the entire grazing season under rotational stocking (Derner et al. 1994). Based on this evidence, we conclude the lower gains per head under rotational stocking were a result of reduced forage intake.

Several previous studies have reported little or no difference in gain per head between continuous and rotational stocking when the methods were tested at equal stocking rates (McIlvain and Savage 1951, Pratchett and Schirvel 1978, Pitts and Bryant 1987, Hart et al. 1988). Heitschmidt et al. (1982) and Sedivec et al. (1990) reported no reduction in gain per head under rotational stocking even when stocking rate was increased over continuous stocking. Comparing continuous and rotational stocking on tobosagrass [Hilaria mutica (Buckl.) Benth.], a coarse bunchgrass, Anderson (1988) reported reductions in gain per head of $33 \%$ with rotational stocking. Our results may differ because potential herbage production was at least twice as high in our study than in these previous studies and the vegetation in our study was dominated by rather coarse $\mathrm{C}_{4}$ grasses. To our knowledge, no rangeland studies have reported increases in gain per head under rotational stocking.

Early season gains were similar to total gains in their response to grazing method (Fig. 3b). Gains were greater $(\mathrm{P}<0.01)$ under continuous stocking and the difference between methods

\begin{tabular}{|c|c|c|c|c|c|c|c|c|}
\hline Year & $\overline{\mathrm{N}}$ & Intercept & $\begin{array}{l}\text { Grazing } \\
\text { method }\end{array}$ & $\begin{array}{c}\text { Stocking } \\
\text { rate }\end{array}$ & $\begin{array}{c}\text { Grazing method } \\
* \text { Stocking rate }\end{array}$ & $\overline{\overline{\mathrm{R}^{2}}}$ & C.V. & 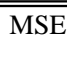 \\
\hline Full season & 12 & $\begin{array}{r}136.4^{1} \\
(5.7)^{2}\end{array}$ & & $\begin{array}{l}-0.294 \\
(0.082)\end{array}$ & $\begin{array}{l}-0.244 \\
(0.029)\end{array}$ & 0.91 & 3.25 & 3.50 \\
\hline Early & 12 & $\begin{array}{l}94.6 \\
(3.4)\end{array}$ & & $\begin{array}{l}-0.240 \\
(0.049)\end{array}$ & $\begin{array}{l}-0.158 \\
(0.017)\end{array}$ & 0.93 & 2.83 & 2.06 \\
\hline Late & 12 & $\begin{array}{l}44.9 \\
(3.9)\end{array}$ & $\begin{array}{l}-5.9 \\
(1.3)\end{array}$ & $\begin{array}{l}-0.100 \\
(0.054)\end{array}$ & & 0.71 & 6.62 & 2.33 \\
\hline
\end{tabular}




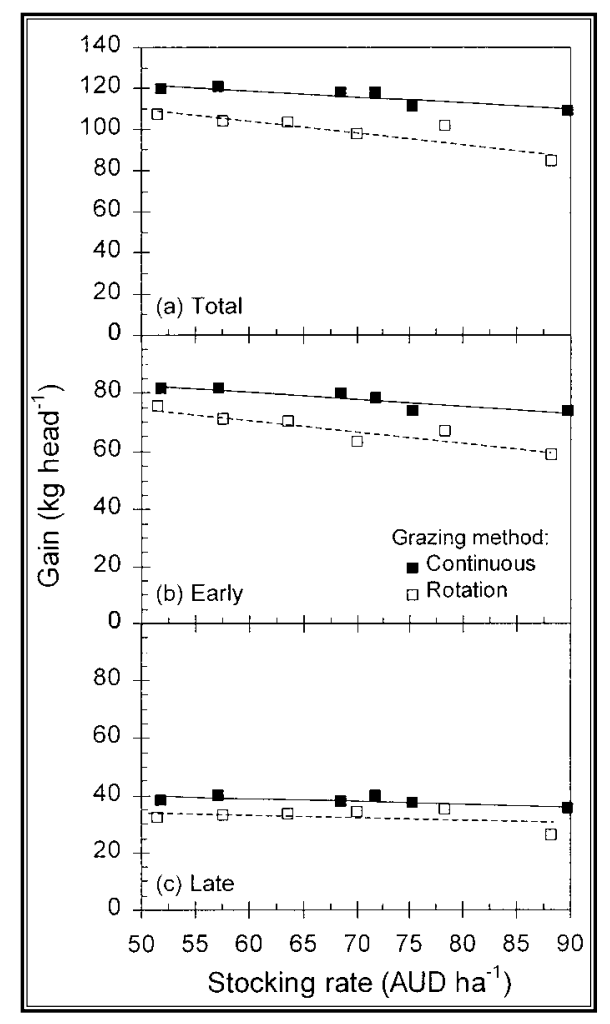

Fig. 3. Average individual steer gain $(\mathrm{kg}$ head $^{-1}$ ) under continuous and rotational stocking methods, 1989 to 1994 . a) total gains; b) gains during the early portion of the grazing period, c) gains during the later portion of the grazing period.

increased with stocking rate. Late season gains were still greater $(\mathrm{P}<0.01)$ under continuous stocking, but the difference was constant across stocking rates (Fig. 3c). The regression model explained less of the variation in gain per head during the late period, especially for rotational stocking (Table 1 , Fig. 3c). Averaged over stocking rate, gain per head was reduced with rotational stocking by $13.6 \%$ in the early period and $15.3 \%$ in the late period.

Gain per head appeared to be more sensitive to stocking rate in the early portion of the grazing season compared to the late portion. The slope coefficient for stocking rate was greater for the early versus late grazing period (Table 2). This result does not agree with previous work. Hart (1978) stated gains should be less sensitive to stocking rate during earlier growing periods because forage quality is uniformly higher at that time. Steer gains in the early portion of the grazing season are not affected by stocking rate under intensive early stocking (Owensby et al. 1988, McCollum et al. 1990). Owensby et al. (1973) reported steer gain with deferred rotational stocking was more sensitive to stocking density in the later portion of the growing season in tallgrass prairie.

\section{Gain per Hectare}

Live weight gain per hectare increased $(\mathrm{P}<0.05)$ as stocking rate increased because the additional animals offset the reduction in gain per head (Fig. 4). Maximum gain per hectare was apparently not reached within the bounds of the experimental treatments.

Gain per hectare was higher $(\mathrm{P}<$ $0.05)$ with continuous stocking at all stocking rates (Fig. 4). This is a direct consequence of the gain per head relationship. If the 2 lines describing gain per head for continuous and rotational stocking do not intersect, the 2 lines describing gain per hectare will also not intersect.

Other studies have compared continuous stocking at a moderate stocking rate and rotational stocking at stocking rates 50-100\% higher (Heitschmidt et al. 1982, Sedivec et al. 1990). Gain per hectare is uniformly greater under rotational stocking in these studies. In this study, gain was $73 \mathrm{~kg} \mathrm{ha}^{-1}$ under con- tinuous stocking at a moderate stocking rate of 52 AUD ha ${ }^{-1}$ and $92 \mathrm{~kg} \mathrm{ha}^{-1}$ under rotational stocking at a very heavy stocking rate of 90 AUD ha ${ }^{-1}$. This is an increase in gain of $25 \%$ for an increase in stocking rate of $69 \%$. However, if the 2 methods are compared at $90 \mathrm{AUD} \mathrm{ha}^{-1}$, gain was $115 \mathrm{~kg}$ $\mathrm{ha}^{-1}$ under continuous stocking versus $92 \mathrm{~kg} \mathrm{ha}^{-1}$ for rotational stocking.

\section{Net Return per Hectare}

Net return per hectare increased as stocking rate increased for both grazing methods (Fig. 5). Net returns were lower for rotational stocking at all stocking rates, a direct result of the gain per head relationship in which continuous stocking held an advantage across the full spectrum of stocking rates. Different price scenarios shifted the net return lines up or down but did not change the relative positions for continuous and rotational stocking or the distance between the lines for the 2 grazing methods. There would be little economic incentive to increase stocking rate with rotational stocking in this situation.

For continuous stocking, the point of maximum net returns did not occur within the range of stocking rates used in the study (Fig. 5). A conservative stocking rate with continuous stocking would be 63 AUD ha ${ }^{-1}$ based on current recommendations from the

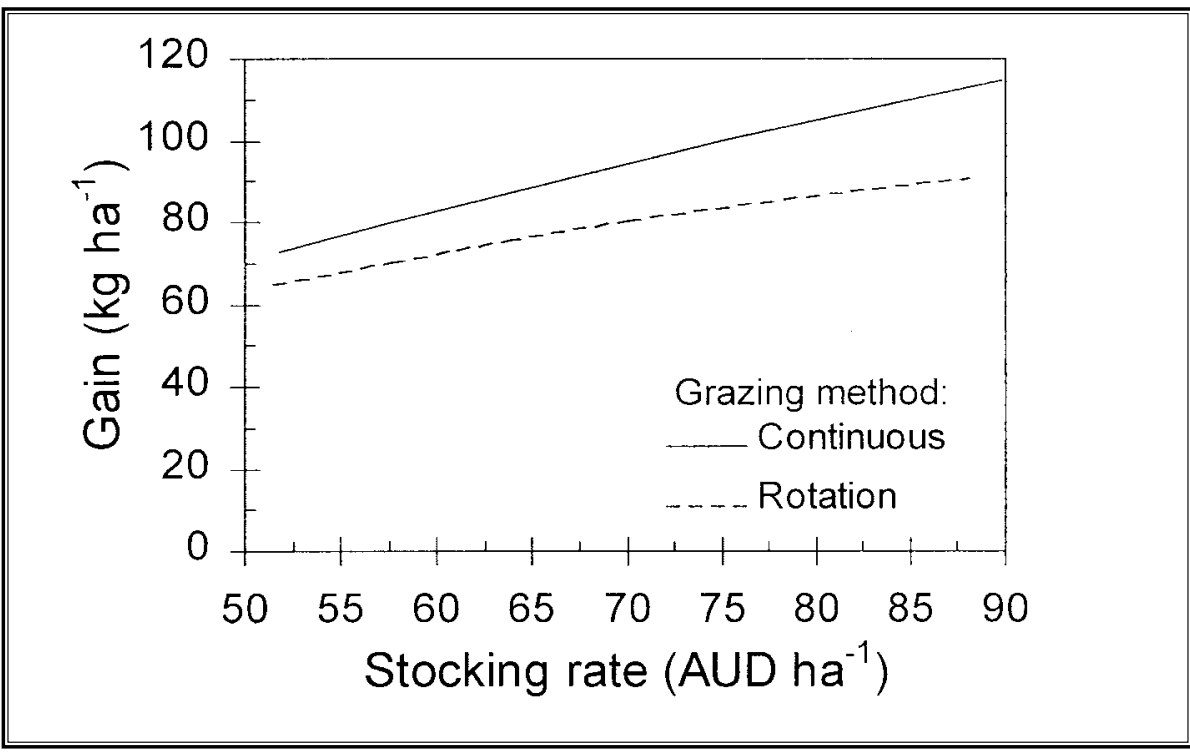

Fig. 4. Average steer gain ha $\mathrm{ha}^{-1}\left(\mathrm{kga}^{-1}\right)$ under continuous and rotational stocking methods, 1989 to 1994. 


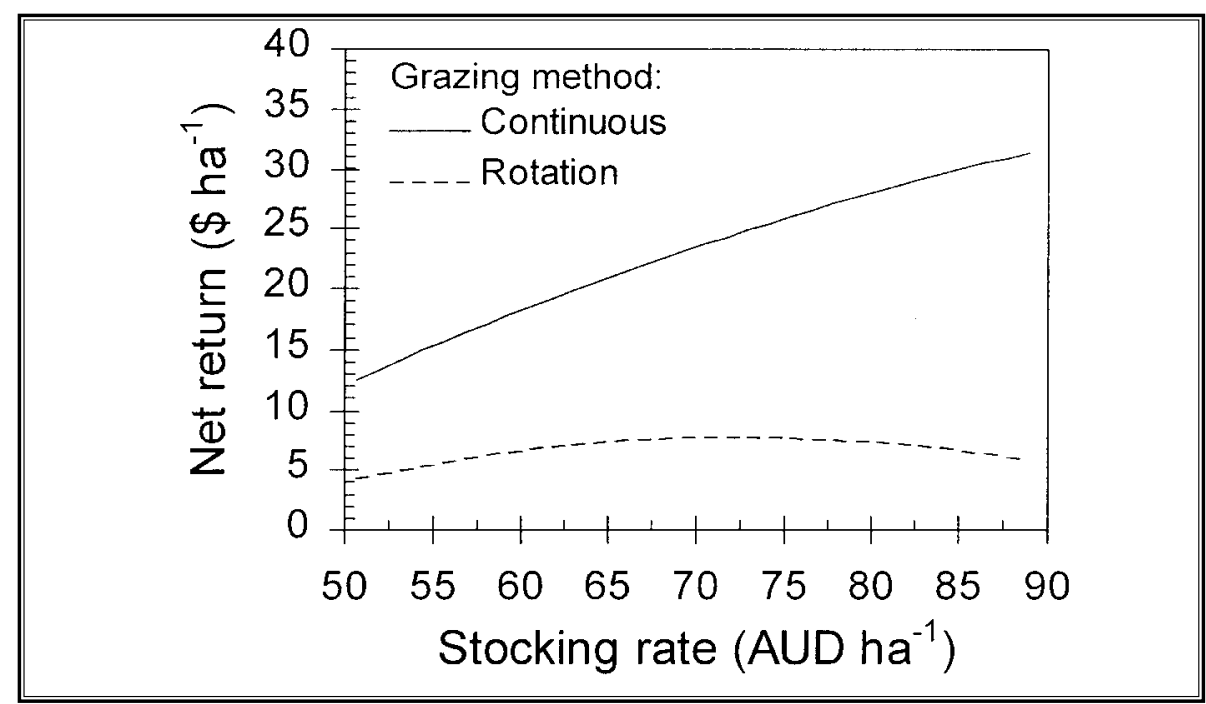

Fig. 5. Average net return ha-1 $\left(\$ h^{-1}\right)$ under continuous and rotational stocking methods, 1989 to 1994.

National Resources Conservation Service. This stocking rate would yield a net return of $\$ 19.87 \mathrm{ha}^{-1}$. The point of maximum net returns did occur within the range of tested stocking rates for rotational stocking. Returns were maximized at $\$ 7.82 \mathrm{ha}^{-1}$ when the stocking rate was 73 AUD $\mathrm{ha}^{-1}$. No stocking rate under rotational stocking gave net returns equal to those achieved with continuous stocking at a conservative stocking rate.

These results actually underestimate the difference in net returns between continuous and rotational stocking. Net returns were calculated on the basis of variable costs of production only. No costs for additional fencing or water were included. If such developments were required for implementation of rotational stocking, the difference in net returns between the 2 methods would increase. Rotational stocking may allow a reduction in variable production costs if labor and other resources can be used more efficiently. In this study, variable costs per head under rotational stocking would have to decrease by $24 \%$ for net returns to be equal between the two grazing methods at 63 AUD ha-1. At a stocking rate of 90 AUD ha ${ }^{-1}$, variable costs for rotational stocking would have to decrease by $34 \%$ to equalize net returns.

Hart et al. (1988) found equal net returns between continuous and rota- tional stocking because gain per head was also equal between grazing methods. Heitschmidt et al. (1990) reported no significant difference in net returns between continuous and rotational stocking when the rotational stocking treatment was stocked at a $60 \%$ higher rate. As with the current study, the higher stocking did not result in greater net return because individual animal performance was reduced under rotational stocking. This implies net returns would have been lower under rotational stocking if stocking rates had been equal between grazing methods.

\section{Conclusions}

Rotational stocking reduced gain per head compared to continuous stocking at all stocking rates. The difference in gain between continuous and rotational stocking increased as stocking rate increased. This fundamental relationship dictated a reduction in gain $\mathrm{ha}^{-1}$ and net return ha ${ }^{-1}$ for rotational stocking at all stocking rates. Performance per hectare was lower under rotational stocking even when comparisons were made between a moderate stocking rate under continuous stocking and a heavy stocking rate under rotational stocking.

It could be suggested that livestock performance would eventually decline under continuous stocking at the heavier stocking rates. This might be caused by a deterioration of the vegetation, which would eventually result in lower livestock performance. While vegetation was not affected by the heavier stocking rates over the study period (Gillen et al. 1998), less favorable environmental conditions could result in a downward trend in range health. It might be further assumed that rotational stocking, because of the planned rest periods, would maintain rangeland health and livestock performance at the heavier stocking rates. In that case, the curves for gain per head might cross and gain per head for rotational stocking might be higher than for continuous stocking. This would lead to higher gain $h^{-1}$ and possibly higher net return $\mathrm{ha}^{-1}$, depending on livestock budgets. Even if this scenario occurred, the manager would forfeit potential income for several years waiting for a response. More importantly, under our conditions, net returns at a sustainable stocking rate under continuous stocking would still be higher than net returns under a much higher stocking rate under rotational stocking. Greater input would be required and higher risk would be assumed for little or no benefit. It should also be reiterated that the higher herbage standing crop under rotational stocking (Cassels et al. 1995) was not a reflection of greater plant vigor but rather reduced forage intake by the steers.

The key to our responses was the decreased weight gain per head. This was related to a decrease in forage intake. Unless the decline in gain per head can be reduced or eliminated by a change in management technique, there is no economic incentive to implement rotational stocking under the conditions of this study.

\section{Literature Cited}

Anderson, D. M. 1988. Seasonal stocking of tobosa managed under continuous and rotation grazing. J. Range Manage. 41:78-83.

Booysen, P. V. and Tainton, N. M. 1978. Grassland management: principles and practice in South Africa, p. 551-554. In: D. N. Hyder (ed.), Proc. First Inter. Rangeland Congr., Soc. Range Manage., Denver, Colo. 
Cassels, D.M., R. L. Gillen, F. Ted McCollum, Kenneth W. Tate, and Mark E. Hodges. 1995. Effects of grazing management on standing crop dynamics in tallgrass prairie. J. Range Manage. 48:81-84.

Derner, J.D., R.L. Gillen, F. Ted McCollum, and Kenneth W. Tate. 1994. Little bluestem tiller defoliation patterns under continuous and rotational grazing. J. Range Manage. 47:220-225.

Gillen, R. L., F. T. McCollum III, K. W. Tate, and M. E. Hodges. 1998. Plant community response to grazing system and stocking rate in tallgrass prairie. $\mathrm{J}$. Range Manage. 51:139-146.

Hart, R. H. 1978. Stocking rate theory and its application to grazing on rangelands, p. 547-550. In: D. N. Hyder (ed.), Proc. First Inter. Rangeland Congr., Soc. Range Manage., Denver, Colo.

Hart, R. H., M. J. Samuel, P. S. Test, and M. A. Smith. 1988. Cattle, vegetation, and economic responses to grazing systems and grazing pressure. J. Range Manage. 41:282-286.

Heitschmidt, R.K., J.R. Frasure, D.L. Price, and L.R. Rittenhouse. 1982. Short duration grazing at the Texas Experimental Ranch: Weight gains of growing heifers. J. Range Manage. 35:375-379.

Heitschmidt, R. K., J. R. Conner, S. K. Canon, W. E. Pinchak, J. W. Walker, and S. L. Dowhower. 1990. Cow/calf production and economic returns from yearlong continuous, deferred rotation and rotational grazing treatments. J. Prod. Agr. 3:92-99.
Howell, L. N. 1978. Development of multicamp grazing systems in the Southern Orange Free State, Republic of South Africa. J. Range Manage. 31:459-465.

McCollum, F. T. III and R. L. Gillen. 1998. Grazing management affects nutrient intake by steers grazing tallgrass prairie. J. Range Manage. 51:69-72.

McCollum, F. T., R. L. Gillen, D. M. Engle, and G. W. Horn. 1990. Intensiveearly stocking on Cross Timbers rangeland. J. Range Manage. 43:99-103.

McIlvain, E. H. and D. A. Savage. 1951. Eight-year comparison of continuous and rotational grazing on the Southern Plains Experimental Range. J. Range Manage. 4:42-47.

Merrill, J. 1983. The XXX Ranch: managing range for ecology and economy, p. 86-95. In: Using Our Natural Resources, 1983 Yearbook of Agriculture. USDA, U.S. Government Printing Office, Washington, D.C.

Myers, H. R. 1982. Climatological data of Stillwater, Oklahoma 1893-1980. Oklahoma Agr. Exp. Sta. Rep. P-821. Stillwater, Okla.

Neter, J. and W. Wasserman. 1974. Applied linear statistical models. R. D. Irwin, Homewood, Ill.

Olson, K. C. and J. C. Malechek. 1988. Heifer nutrition and growth on short duration grazed crested wheatgrass. J. Range Manage. 41:259-263.

Owensby, C. E., R. Cochran, and E. F. Smith. 1988. Stocking rate effects on intensively-early stocked Flint Hills bluestem range. J. Range Manage. 41:483-487.
Owensby, C. E., E. F. Smith, and K. L. Anderson. 1973. Deferred-rotation grazing with steers in the Kansas Flint Hills. J. Range Manage. 26:393-395.

Pitts, J. S. and F. C. Bryant. 1987. Steer and vegetation response to short duration and continuous grazing. J. Range Manage. 40:386-389.

Pratchett, D. and B. Schirvel. 1978. The testing of grazing systems on semiarid rangeland in Botswana, p. 555-557. In: D. N. Hyder (ed.), Proc. First Inter. Rangeland Congr., Soc. Range Manage., Denver, Colo.

Savory, A. 1978. A holistic approach to ranch management using short duration grazing, p. 555-557. In: D. N. Hyder (ed.). Proc. First Int. Rangeland Congr., Soc. for Range Management, Denver, Colo.

Sedivec, K. K., T. A. Messmer, W. T. Barker, K. F. Higgins, and D. R. Hertel. 1990. Nesting success of upland nesting waterfowl and sharp-tailed grouse in specialized grazing systems in southcentral North Dakota, p.71-92. In: K. E. Severson (ed.), Can livestock be used as a tool to enhance wildlife habitat? USDA-FS Gen. Tech. Rep. RM194. Ft. Collins, Colo.

Vallentine, J. F. 1990. Grazing management. Academic Press, New York, N. Y.

Wilson, A. D. and N. D. MacLeod. 1991. Overgrazing: present or absent? J. Range Manage. 44:475-482. 